\title{
THE POLITICAL ANALYSIS OF ECONOMIC MARKETS
}

\section{Alan Cawson}

\section{INTRODUCTION}

There is a long tradition of the application of economic theories to 'political' phenomena, such as voting behaviour or the behaviour of bureaucracies, but it is only relatively recently that sociologists and political scientists have attempted to use their theories to explain 'economic' phenomena. In this article, I will show how concepts drawn from Max Weber's theory of social closure can help to interpret changes in the British consumer electronics industry in the 1970s and 1980s, focusing in particular on the processes by which the industry passed almost entirely into Japanese ownership by the mid-1980s. The article begins by presenting, in schematic terms, a framework for understanding 'the market' in terms of dynamic social processes. The section that follows presents a brief overview of the consumer electronics industry in the early 1970s, and then analyses in some detail the way in which power was exercised as the domination of the industry by British firms was eclipsed. Finally, I offer some suggestions as to how the political analysis of markets might be further developed.

\section{SOCIAL CLOSURE AND USURPATION}

Weber's approach to understanding the operation of markets was based on the fundamental point that markets are essentially social processes, where parties to market transactions develop a social relationship. Unless in each case the transaction is both the first and the last between the two parties, some kind of continuing relationship is established, which to some extent at least is ordered by norms and moral considerations. The social aspect of market relationships is not limited to those between buyers and sellers, since sellers (and in many cases buyers also) can orient their actions towards each other through competition or collaboration.

Competition within markets is thus also a social process (and not the impersonal mechanism beloved of economics textbooks), and is properly seen as a struggle: 'a formally peaceful attempt to attain con- trol over opportunities and advantages which are also desired by others'. ${ }^{1}$ Success in this competition is thus equated with power: firms which are successful in denying advantages to their competitors are in a position to exert power over them, and once power is attained it tends to be defended. It is this process of achieving and defending privilege that Weber defines as social closure: a process in which power is exercised to exclude others from access to those opportunities. It is clear from Weber's account that the essential dynamic of the market is not competition (in the sense that economists equate markets with competition) but closure: the tendency towards the development of monopoly power. Thus regulation is required in order to counter this tendency and to sustain relatively open access to opportunities; far from state intervention always driving out competitive processes, public authority is a nécessary (but not sufficient) condition for competitive markets. But state power can also be exercised to maintain closure, through such public policies as nationalisation, fostering 'national champion' firms, and protectionism. The firms themselves may seek help from public authorities in defending their privileges, action which may be regarded as protecting a national interest, or a strategic technology.

We can identify a number of different strategies through which economic actors (in this case, firms) seek to achieve a dominant position in the market, i.e. different modes of social closure within the market. For the purposes of this analysis, a broad categorization of three types of closure will be sufficient: closure through competitive struggle, closure through associative action, and closure through the state.

In the first of these, firms orient their strategy aggressively towards other producers through exploiting any competitive advantage they might perceive. In the case of the electronics industry, such advantages will tend to come from innovation, and in some cases closure may be reinforced through legal means, as with patenting. As we shall see in the next section, 
the source of innovation may be either new products or new ways of making existing products, and closure around product innovation may not be sufficient to protect market power against firms which are able to take advantage of process innovations to reduce manufacturing costs.

In the second strategy, closure through associative action, firms define their interests collectively in terms of avoiding the kind of competition involved in the first strategy. Such action is most common where relatively small numbers of firms are involved, and in relatively mature industries where the pace of product innovation has slowed. At one extreme, closure takes the form of the cartel, where firms agree formally (even if illegally) to carve up the market and remove competition altogether. More common, and relevant to the case which follows, is the formation of a collective identity through an industry or trade association, where an informal regulatory order is developed in which common understandings between firms moderate the extent of competitive behaviour.

The third form of closure strategy is where a firm or firms seek to protect their dominant position by invoking the authority of the state; or, alternatively, when governments seek to achieve industrial policy goals by privileging a particular firm as a 'national champion' with subsidies, favoured purchasing and so on. Firms may demand that governments enact protectionist measures, or take other steps to insulate the firms from competitors.

Each of these strategies is defined here as an ideal type; in actual situations firms may pursue two or even all three of these strategies at the same time given that they operate in different time frames. In the mid-1980s, for example, the response of Philips to the ferocious competition from Japanese firms in the video recorder market was to seek protection from the European Commission, coordinate collective action through the European Association of Consumer Electronics Manufacturers (EACEM), and invest heavily in new products and process technologies. Closure through the state in the form of an EC-negotiated voluntary export restraint agreement with the Japanese was a short-term solution, action

2 For an extended discussion of usurpation developed from Weber, see Frank Parkin, Marxism and Class Theory: A

Bourgeois Critique (London: Tavistock, 1979).

3 For a more detailed discussion of the empirical material in this article, see A. Cawson, K. Morgan, D. Webber, P. Holmes and A, through EACEM was a medium-term response, and closure through innovations such as digital sound recording and multimedia technologies was a longerterm effort to re-establish a dominant competitive position.

As we have noted, closure involves the exclusion of others from opportunities within the market. It is hardly surprising that those who are excluded will seek admission, and in Weberian theory the process of seeking to undermine the basis of social closure is known as usurpation. ${ }^{2}$ We can also distinguish different types of usurpation strategies which correspond to the three kinds of closure strategies identified earlier; that is, through competitive action, through associative action, or through the state. Successful usurpation creates in turn the basis of social closure, so that we can see as the essential dynamic of market processes a continual dialectic unfolding over time between closure and usurpation whereby power relations are subject to challenge and relations of domination are under threat from the dominated.

The following analysis applies these concepts to the British consumer electronics industry over two decades. ${ }^{3}$ It shows how the existing firms in the industry (largely British-owned) were displaced (usurped) by foreign firms, principally because by fostering an inward-looking stance through membership of the trade association, the firms failed to anticipate the nature of the usurpation strategies of the Japanese firms. In this case, the social (in the conventional as well as the Weberian sense) relationships between producers inhibited their ability to react strategically to the threat to their dominant position.

\section{THE DYNAMICS OF THE BRITISH CONSUMER ELECTRONICS MARKET}

The principal product of the major consumer electronics firms in Britain in the 1970s was colour television. The switch from black and white sets in the late 1960s had created an exceptional set of opportunities for the firms, since the new colour technology (PAL - phase alternation by line) had been invented by Telefunken in Germany and crosslicensed to Thorn in Britain, which enabled those

Stevens, Hostile Brothers: Competition and Closure in the European Electronics Industry (Oxford: Clarendon Press, 1990); and A. Cawson, 'A high tech industry: consumer electronics', Unit 13 of D212 Running the Country, (Milton Keynes: Open University Press, 1992). The research was supported by the Economic and Social Research Council. 
firms to control entry to the industry. Initially, licences were only available to foreign firms for small-screen sets (which formed a tiny proportion of the British market) and to those firms which established manufacturing plants in Britain. The sets were complex, and expensive, and at $£ 500$ were the same price as the cheapest car.

At the beginning of the decade nine firms were producing colour TVs - seven British, one Dutch and one American. They all belonged to the British Radio and Electronic Equipment Manufacturers' Association (BREMA), which, although it did not function as a formal cartel controlling supply and prices in the industry, did serve to orient producers' actions towards each other by the exchange of information about prices and quantities. The shared perceptions and informal monitoring of the market led BREMA members to the view that their interest lay in maintaining high prices and margins through the moderation of competition, and the informal agreement served to reduce the pressure on firms to seek innovations in the products themselves, or the way in which they were manufactured. Thus closure through associational action was the preferred strategy of the firms.

The Japanese firms, who had been allowed under the terms of the PAL licence only to produce smallscreen sets, began to make very rapid inroads into the overall colour TV market. Their own trade association, the Electronic Industries Association of Japan (EIAJ), had established a European branch in Dusseldorf in 1962, and since then had been supplying market intelligence to its member firms. The BREMA firms had no comparable understanding of the way in which the Japanese firm operated, since markets in Europe were tightly segmented along national lines, and none of the firms had any interest in competing on the Japanese market.

The reaction of the British firms to the erosion of their market share was to cry foul, and to suggest that the Japanese TV sets were being dumped at below their market price. This was an understandable reaction when Japanese quality/price combinations were judged against British manufacturing costs and practices. The newly-formed Sectoral Working Party (SWP) of the UK National Economic Development Office decided to investigate, and commissioned the Boston Consulting Group to undertake a comparative study of television manufacturing in Britain, Germany, Korea and Japan. The conclusions of the report were so explosive, and potentially damaging to the British firms, that SWP members were sworn to secrecy. The report showed that Japanese firms achieved their significant cost and quality advantages over the British through innovations in set design (reducing the number of components) and in manufacturing (through using machines to insert components automatically). Moreover, the most modern plants in Japan could make 1 million sets per year against the British industry average of 250,000 .

At this point, the closure strategy of the firms switched from associative action to a state-backed mode. The SWP agreed a major programme of plant closures and rationalization, which would have reduced the number of firms in the industry and created much larger plants. Some $£ 80$ million of government aid was sought, but the general election of 1979 occurred before the plan could be realised, and the incoming Thatcher government was implacably opposed to such industrial policy solutions.

In anticipation of the adoption of other kinds of state-backed closure strategies, such as import restrictions and tariff increases, the Japanese firms began to establish factories in Britain, beginning with Sony and Matsushita in 1974 and 1976 respectively. Under severe pressure from the domestic industry, especially from Philips (ironically not British-owned), the government persuaded later entrants into joint ventures with British firms (GEC with Hitachi and Rank with Toshiba). From 1977 until 1985, there was an informal ban on greenfield investment in the consumer electronics industry by Japanese firms.

The experience of these 'shotgun weddings' highlighted the very considerable differences in the way in which British and Japanese firms operated, reflecting in broad terms differences between firms employing closure strategies to defend an established position, and firms seeking to usurp those privileges. Whereas the British firms relied on informal understandings developed within the context of the industry association to regulate competition, the Japanese firms employed all three types of usurpation strategy combining elements of keen competitive behaviour, effective associational action, and the exploitation of government industrial policies.

The most important aspect of competitive behaviour was an emphasis on product quality and reliability in part arising from higher levels of automated 
assembly, but also consequent upon long-term, closely supervised relationships with component suppliers. This kind of competitive strategy was unusual in the Western electronics industry, where components tended to be bought on short-term 'spot' contracts. The reputation of Japanese televisions that became quickly established was symbolized by the fact that identical televisions coming off the GEC-Hitachi line were sold at a $£ 40$ premium if they were badged 'Hitachi'.

The Japanese firms also brought with them distinctive managèrial and industrial relations strategies which helped them to implement quality-based manufacturing programmes. In many cases single union agreements were introduced which embodied defined procedures for arbitration of disputes. In such cases, new entrants have considerable advantages over incumbent firms, who may have to negotiate with several unions and who may have established working practices which make innovations in manufacturing processes more difficult.

The organizational skills of the EIAJ were also a significant factor in assisting the Japanese firms to usurp the dominant position of the British companies. Japanese subsidiaries joined the domestic trade association BREMA in order to appear as good corporate citizens, and tended to send their British managers to BREMA meetings. But for technical and market intelligence they relied on a system of parallel representation coordinated through the EIAJ office in Dusseldorf. Among the services offered to the firms by the EIAJ was the important one of offering advice on plant location and the availability of government subsidies.

The third aspect of the Japanese firms' usurpation strategy should not be neglected: the exploitation of regional and industrial policies to offset some of the cost and risk of inward investment. The first investment by Sony in 1974 had been in a development area in Wales, for which about 18 per cent of the initial investment was provided by the government. Later on, when there began to be considerable competition between European governments to attract inward investment, the brokerage skills of the EIAJ became particularly important. The decision by Sharp in 1985 to open a video recorder factory in
North Wales was considerably influenced by exceptional levels of government assistance, amounting to $£ 6.5$ million of a $£ 10$ million investment. For firms like Thorn EMI, who were based in 10-year old plants in the South-east of England, the competition coming from purpose-built factories employing a hand-picked workforce in development areas was seen as unfair, and there was considerable resentment at government policies which seem to make usurpation easier.

The outcome of this process was the steady exit of British-owned firms from the industry. In 1967 eight out of ten firms making televisions were Britishowned; in 1989 there was the same number of firms, but none was British.

\section{CONCLUSIONS}

This article has outlined in schematic terms the process of competition within a single product market over a 20 year period. I suggested that the outcome - the displacement of one set of firms by another - could best be explained through making use of a framework which recognized the importance of relations of power and domination within markets. This framework recognizes that competition is far from being an impersonal mechanism or an invisible hand, but is in practice a highly political struggle between producers. Economic actors operate within a social context, and their capacity to respond is constrained by the nature of those social relations, both within their organizations (i.e. the firms) and between them within industry associations and in their relationships with government. The framework sketched three principle types of closure and usurpation strategies, and the case study showed how these strategies were combined in practice, although the most striking feature of the case is the unwillingness of the British firms to respond through economically-oriented competitive behaviour. Instead, the firms (unsuccessfully) sought to defend their dominant position through seeking protection from the state. The collective ethos fostered through their industry association prevented the firms from recognizing the nature of the competitive threat to which they were exposed. By the time they did realize this, it was probably too late to respond by increasing competitiveness.
4 See the series on Government-Industry Relations published by Clarendon Press; L. Lindberg, J.R. Hollingsworth and J. Campbell, eds., Governing the American Economy (Madison: University of
Wisconsin Press, 1991); J.R. Hollingsworth, P.C. Schmitter and W. Streeck, eds., Comparing Capitalist Economies (New York: Oxford University Press, 1993). 
Similar studies of other industrial sectors ${ }^{4}$ suggest considerable differences in the way in which 'sectoral governance' takes place, with differences in industry structure (such as number and size of firms) providing only a partial explanation for these. Research on the organization of Japanese industry places considerable emphasis on networks of inter-firm relationships both vertically (in terms of supplier chains) and horizontally (in terms of associations of firms cutting across sectoral boundaries). At the very least, the typology of closure strategies employed in this article would need to be considerably refined in order to accommodate inter-firm networks which are not formalized within an industry association. Such networks themselves show considerable vari- ety, from short-term agreements, for example, in R\&D collaboration, to stable groups existing over long periods reinforced by cross-shareholdings.

Compared to the simple elegance of formal economic models, the political analysis of economic markets reveals a good deal of complexity and variety. The available tools for making sense of this are admittedly crude, and require refinement through extensive empirical research. Now that the results of such research across different industrial sectors and different market economies is beginning to become available, we should be in a better position to undertake the task. 